Magnetic exchange bias of more than 1 Tesla in a natural mineral intergrowth SUZANNE A. MCENROE, BRIAN CARTER-STIGLITZ, RICHARD J. HARRISON, PETER ROBINSON, KARL FABIAN \& CATHERINE MCCAMMON

Nature Nanotechnology 2, 631-634 (2007).

In this letter, reference 5 was incorrect. The correct reference is as follows:

Noguès, J. et al. Exchange bias in nanostructures. Phys. Rep. 422, 65-117 (2005).

\title{
Downscaling of self-aligned, all-printed polymer thin-film transistors
}

YONG-YOUNG NOH, NI ZHAO, MARIA CAIRONI AND HENNING SIRRINGHAUS

Nature Nanotechnology 2, 784-789 (2007).

In figure $2 \mathrm{~d}$, the units for the drain current were incorrectly given in amperes $(\mathrm{A})$. The correct units should be microamperes $(\mu \mathrm{A})$. 